\title{
Understanding the Application of Photovoltaic Technology for Public Transportation
}

\author{
Saeful Bahri ${ }^{1 *}$, and Ari Widyati Purwantiasning ${ }^{2}$ \\ ${ }^{1}$ Department of Electrical Engineering, Faculty of Engineering, Universitas Muhammadiyah Jakarta, Indonesia \\ ${ }^{2}$ Department of Architecture, Faculty of Engineering, Universitas Muhammadiyah Jakarta, Indonesia
}

\begin{abstract}
.
This research is aiming to explore and understand the application of photovoltaic technology particularly in transportation facilities for public users. This research is a first year study which is a part of two-year research. While there are many types of public transportation, this research have a significance type of public transportation which have a particular need for local community within historical area. Furthermore, this research is also aiming in the identification of an appropriate public transportation which suitable to be implemented within historical area. This research has implemented the qualitative method using some theories which have been applied to promote the perfect public transportation to be implemented.
\end{abstract}

Keywords: photovoltaic technology, solar cell, public transportation, tram, historical area 


\section{Introduction}

One of a basic concept in Transit Oriented Development is connecting people from one place to another place easily and to do activities within one area to reduce the using of private vehicle. Historical area is one of the most significant area which has a unique character, and usually this area is lack of utilities to support the need of the community. To enhance the quality of this historical area, some innitiatives should be done by local government together with all related parties. This research is aiming to propose the idea to provide public transportation within historical area to support the implementation of Transit Oriented Development's concept. This public transportation is not just a transportation within historical area which connecting from one place to another place, but also has a particular technology named photovoltaic technology to be implemented at the public transportation.

One of the idea to implement the photovoltaic technology for public transportation is by using a solar cell. As mentioned by Güneşer, et.al (2015) [1], one of the vehicle that could implement solar cells is a solar electric vehicle (SEV). Solar electrical vehicle is an electric vehicle with onboard photovoltaic cells charging a set of batteries for extended driving range. He also mentioned that solar vehicles can also be designed for transportation on short distance, as between one building to another one within a particular area [1]. We believe by implementing this solar electrical vehicle within historical area, it will become a suitable solution for this area's need.

This research is a part of a research to propose a suitable concept for historical sites in Indonesia, particularly Jakarta as a metropolitan city with Jakarta Old Town Area as the historical site. This research has been done to synergize the concept with a research of Transit Oriented Development to enhance and improve the quality of the built environment as well as the quality of local community significantly. As a part of multi-year research, this paper is aiming to provide some types of public transportation to have an understanding of Photovoltaic Technology for public transportation. By understanding the concept of photovoltaic technology for public transportation, it can be concluded and proposed the suitable public transportation to be implemented within historical site of Jakarta. Although this paper is an initial result, it will become the basic thought to do more and to implement it within a case study conducted in Indonesia, generally and Jakarta as a metropolitan city, particularly.

\section{What is Photovoltaic Technology?}

\subsection{Basic Theory of Photovoltaci Technology}

Bahri, et.al (2018) [2] has explained that energy thermal which has been produced from the sun could be used to produce another energy to fulfill the human need such as energy thermal to make hot water as a heat source in heater machine cycle as moving energy. He has also mentioned that the using of solar energy has another benefit to produce electricity through the using of photovoltaic cell. For the future, the using of solar energy could become an alternative solution for renewable energy. There are many scholars have done and explained that the using of solar energy could minimized the use of electrical energy. Referring to the previous research of Purwantiasning, et al. (2017)[3] in Bahri, et.al (2018) [2], the using of electrical energy from solar energy by implementing the technology of control system for Fatahillah Museum, one of a historical building in Jakarta Old Town, could be maintained and minimized to $30 \%-60 \%$. This research shows that the using of technology in reducing electricity could become a perfect solution for historical site particularly Jakarta Old Town. 
As mentioned in previous research, Bahri, et.al (2018) [2], the word photovoltaic is referring to Greek; photos mean light and volta implies the name of a physician from Italy who found the electricity. In a simple way, photovoltaic could be defined as electricity from light. Photovoltaic also could be defined as a process to convert light energy (sun) become electrical energy. This statement has supported the explanation of some scholars who performed at the Bell Laboratories in the 50's which has been explained by REN21 (2009) in Rizzo (2010) [4]. Rizzo (2010) [4] has explained that the conversion from light into direct current electricity which has been applied for the first time and has been discovered by Alexandre-Edmond Becquerel (1820-1891). Basically, the panels of photovoltaic have working to the semiconductive properties of silicon and other materials, were first used for space applications. He also mentioned that the diffusion of this technology has been growing exponentialy in recent years, due to the pressing need for the renewable and carbon-free energy.

Rizzo (2010) [4] in his research also mentioned that most of the today PV panels, with multicrystalline silicon technology, have efficiencies between $11 \%$ to $18 \%$, while the use of mono-crystalline silicon allows to increase the conversion efficienct of about $4 \%$. It could be concluded that the cost of these latter solutions is still too high for a mass application on private vehicle.

Furthermore, the book of Basic Photovoltaic Principles and Methods (1982)[5], support the statement that the physical phenomenon responsible for converting light to electricity-the photovoltaic effect was first observed in 1839 by a French physicist, Edmund Becquerel. He mentioned that a voltage appeared when one of two identical electrodes in a weak conducting solution was illuminated. The PV effect was first studied in solids, such as selenium, in the 1870s. In the 1880s, selenium photovoltaic cells were built that exhibited 1\%-2\% efficiency in converting light to electricity. Selenium converts light in the visible part of the sun's spectrum; for this reason, it was quickly adopted by the then-emerging field of photography for photometric (light-measuring) devices. Even today, light-sensitive cells on cameras for adjusting shutter speed to match illumination are made of selenium [5].

It has been stated as well in the book, that today, photovoltaic systems are capable of transforming one kilowatt of solar energy falling on one square meter into about a hundred watts' of electricity. One-hundred watts can power most household appliances: a television, a stereo, an electric typewriter, or a lamp. In fact, standard solar cells covering the sun-facing roof space of a typical home can provide about 8500-kilowatt-hours of electricity annually, which is about the average household's yearly electric consumption. By comparison, a modern, 200-ton electric-arc steel furnace, demanding 50,000 kilowatts of electricity, would require about a square kilometer of land for a PV power supply [5].

\subsection{An Application of Photovoltaic Technology for Public Transportation}

Many researches have been done by scholars to define the effectiveness and the benefit of using photovoltaic technology such as solar panels to reduce the using of electricity. Although there are many researches about it, almost all the studies are focused on the using of solar panels for private vehicle in this case is private car [1][4][6][7]. This research will reveal how important the using of solar panel cells for public transportation. The implementation of the technology is almost the same with the private vehicle or cars, but there is the difference for the need and the amount of the energy. As we know that the public transportation will be provided for local community, thus the need of the space for the vehicle will be bigger than private vehicle or car. This condition of course will affect to the need of the energy for public transportation to be movable from one spot to another spot. 
As mentioned by Izco (2010) [7], that the using of private vehicle will affect to the producing of global warming because these private vehicles will produce emissions of $\mathrm{CO}_{2}$. Actually, the producing of $\mathrm{CO}_{2}$ not just from private vehicles but also from public transportation such as bus, tram, minibus, train etc. Izco (2010)[7] also stated that to solve the problem, there are some important alternative energies that could be delivered. They are solar energy, wind energy, wave energy, blue energy, water power, tidal energy, geothermal energy, and biomass energy. But in this research, referring to the need of reducing the using of electricity, Izco (2010)[7] reduced all those alternative energies into two significant energies: solar thermal and solar photovoltaic energy. Since that solar thermal energy has been used to heat things, the solar photovoltaic energy has been used to generate electricity. Thus, the perfect solution in this case is to deliver and provide the using of photovoltaic energy for vehicle particularly public transportation.

Some studies have mentioned that to apply the using of solar energy to generate electrity, it is needed to understand the basic technique in the application of the energy. Izco (2010)[7] stated there are two types of applications of the solar energy:

1. Network-connected systems

2. Autonomous systems or isolated

As izco (2010)[7] has done his research in implementing the technology of photovoltaic for a car. This research has developed the knowledge to be implemented for public transportation. The energy of the solar will be directly apply to the surface of the vehicle to absorb the solar energy and convert it to the electricity energy (see Figure 1). 


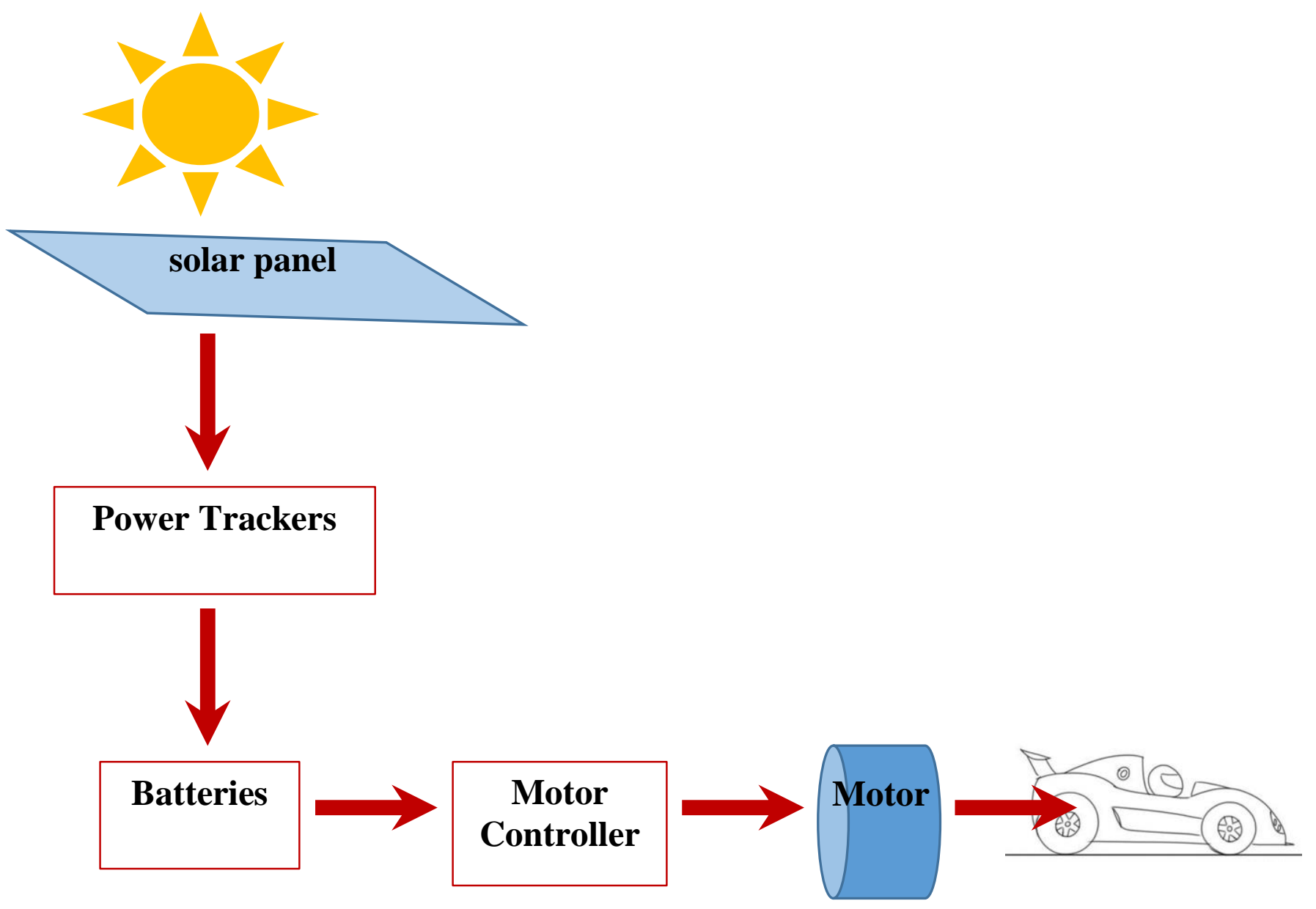

Basically, the scheme of solar car which is shown in Figure 1 is the same with the scheme of solar vehicle for public transportation. The basic concept is to generate electricity through alternative energy of solar energy. The energy from sunlight which go through directly to the solar panels can be converted into other energy forms that could distribute and transfer the electrical energy easily. This process will use some devices known as photovoltaic cells that has a function to convert light energy, photons, into electric current, electrons. This devices of photovoltaic cells are a type of cells that capable to produce an alternative electical energy. This photovoltaic cell can be formed by a sheet of gold or silver, silicon and iron-nickel base.

Taft (2016)[8] has mentioned, although it is very expensive to produce a solar-powered vehicle, but this technology will increase in efficiency and decrease in cost and will support the sustainability of environmentally friendly because this technology will reduce the production of pollution. 


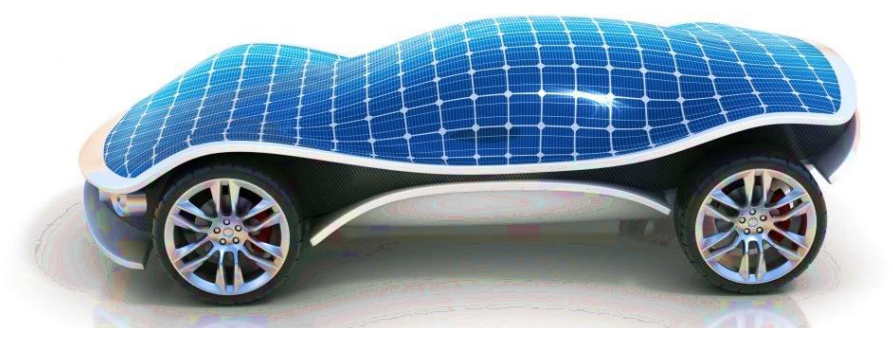

\subsection{Types of Public Transportation}

Public transport generally could be defined as a transport which have been provided to support the mobility of community in large amount of people. Public transportation usually have delivered a system that could cover urban need, suburban need and also regional need from one city to another. This paper has discussed public transportation within a metropolitan city which will deliver and cover urban need as well as suburban need.

Public transportation have been regarded as the most effective and efficient transportation system in metropolitan city to bring people from one place to another without using any private cars. This is will support the need of the city as a smart and sustainable city. One of the problem in the using of public transportation is the safe and the comfort of the facilties. Usually public transportation are not as comfort as a private vehicle, and this is become an issue that suppose to be handled by the local government. The local community should be encouraged to use public transportation to support the sustainability of the city.

Public transportation in metropolitan city usually have many types. The most familiar public transportation in all cities in the world is public bus and public train. Public train could be tram (light train) or metro which is known as Mass Rapid Transit or MRT in most cities in the world. To define the types of public transportation, we have tried to classify the types as follow:

\section{Bus}

This type of public transportation is the most familiar among local community either in the urban area or in suburban area. This public transportation is the most easiest vehicle that could be reached in all areas or spots. The bus networks usually also the most easiest and accessible for people.

\section{Tram}

This particular public transportation is the significant vehicle that usually has been provided in metropolitan city which is accessible to get from one place to another with large numbers of passengers but not as crowded as train. Usually tram has been provided to support an area with a significant need such as historical area, specific area with specific character. Using this public transportation is also doing travelling for leisure.

\section{Metro/ Mass Rapid Transit}

Almost all metropolitan cities in the world have this kind of public transportation. This transportation is very suitable with the city which has high density of 
population. The metro could accommodate large number of passengers and has been regarded as the most effective and efficient transportation system, because the transportation system and network usually is separated with the transportation system which using usual road, thus it avoids the traffic.

\section{Light Rail/ Commuter Line}

This public transportation system is almost the same with Metro or MRT, but usually this light rail is only to provide not just for urban network but also suburban network. Usually this transportation system is become a feeder for Metro or MRT to continue to the network in urban area.

\section{Train}

Usually this kind of public transportation has been used to accommodate people to travel from one city to another. The number of passenger using this public transportation is relatively growing. To support this transportation system, local government also has provided an integrated transportation system between train, commuter line, metro/ MRT, tram and bus. Usually this integrated system is provided in the form of integrated terminal for public transportation. This integrated system will allow passengers to change the public transportation in one place as their need.

\subsection{Suitable Public Transportation for Historical Sites}

Historical site is an area with a specific and significant character which is usually located in the center of metropolitan city. Referring to the previous research of Purwantiasning (2018)[9], the main problem within historical area is the lack of utilities which is one of the utilities is infratsructure. To handle this issue, there is an alternative solution that could be proposed to increase and enhance the quality of the built environment as well as to enhance the quality of llfe the local community within the area. The quality of historical site also depends on the quality of historical buildings within the area. As Purwantiasning (2013)[10] stated that historical site and historical buildings within it are shaping the identity of a particular city.

Furthermore, to identify what is historical site, we need to define what the conservation is. Purwantiasning (2018)[9] has defined that conservation is a concept that aims to manage a place or historical area, as well as historical objects such as buildings or monuments by applying a particular treatment, and to preserve the values of such historical objects which also should then become a part of the identity of the city. Historical area which has to be designated as a conservation area should has a significant character which has special value either tangible or intangible. The initiative of the local government to designate the historical site to be a conservation area is aimed to strengthen the image of the area as well as to influence the quality of surrounding area which is regarded very meaningful to improve the quality and the image of the environment. According to previous research of Purwantiasning (2018)[9], the designation of conservation area is not olny related to the requirement of the local regulations, but is also connected to the needs of the local community. The activity of conservation in improving and enhancing the quality of environment should describe how the places, particularly historical sites, could be experienced by local people who live and work there as well as by visitors, who will have a direct impact on the area. The impact should be related to the contribution to the area, particularly to its setting and appearance and the quality of life of the local community. 
As mentioned in the previous chapter about the types of public transportation, there is a possibility to apply the suitable public transportation within historical site. To choose the suitable public transportation, we have related to the need of historical site particularly the requirement of local regulations. The public transportation which has been conducted should not decrease the quality of the environment within historical site as well as not to make visitors and local community uncomfortable. We have identified some criteria that should be analyzed in the applying the suitable public transportation within historical site, as follow:

1. the vehicle will not destroy the environment particularly the historical site

2. the vehicle will not decrease the character of the historical site

3. the vehicle will make the local community and visitors safe and comfort

4. the vehicle will connect one place to another place easily

5. the vehicle will not disturb the existing activity within historical site

6. the vehicle will transit people effectively and efficiently

7. the vehicle will enhance the quality of the historical site

According to the above criterias, we have conducted tram as a suitable public transportation within historical site. We have conducted tram, because there is a minimum construction which will be applied within historical site, thus there will be minimized the damage within historical site. Using photovoltaic technology which will be applied on the tram's surface or roof will also become the most possible. The tram has also been regarded as a relative small public vehicle that possible to be applied within historical site without making large development. The unique design of the tram also would become an excellent new object with a specific character within historical site.

Referring to Vajihi (2017)[11], there is the first train in the world that has adopted and implemented solar photovoltaic (PV) panels to generate the train in 2012. The name of the train is UNESCO Heritage Himalayan Queen Train from Kalka to Shimla in Northern India. The number of the coaches are seven and there are $200 \mathrm{~W}$ PV modules were installed on the roof of each coach. The generated energy is store in 2x65 AH Sealed Maintenance Free Tubular $24 \mathrm{~V}$ baterries. Each coach has been installed with a 100-watt solar panel with which the coaches can be generated for two days without the sun and can completed two trips to Shima (for about 85 $\mathrm{km}$ per trip/ 3 hours). We have adopted this reference to propose the tram within historical site of Jakarta Old Town Area. Since that the area is not too large, we have decided to conducted one unit tram to be operated within the historical area per trip. This idea has been formed to justify the seven criteria we have mentioned above.

\section{Research Method}

This research has implemented the qualitative method with literature study as a main method for gathering information. We have conducted some literatures to get the understanding for the photovoltaic technology as a main topic in this research. This research is a part of twoyear research which is undertaken to promote an alternative and an appropriate solution for public transportation within historical site in Indonesia, particularly Jakarta as a metropolitan city. From this initial study, we have concluded the suitable public transportation which will be implemented within historical site In Jakarta. To decide the appropriate and suitable pubic transportation, we have studied the character of the historical area in Jakarta, particularly Jakarta Old Town Area, and we have underlined the character of the local community as well who will use the facility within the area. 


\section{Discussion of Case Study}

\subsection{Jakarta Old Town Historical Site}

According to the Guidelines of Jakarta Old Town (2007)[12], the historical site of Jakarta Old Town has been divided into five zones. They are Zone 1-Sunda Kelapa, Zone 2-Fatahilah, Zone 3-Pecinan or China Town, Zone 4-Pekojan or Kampung Arab, and last one is Zone 5Kawasan Peremajaan or Rejuvenation Area. The area of Jakarta Old Town has a core zone which consists Zone 1-Sunda Kelapa, Zone 2-Fatahillah, Zone 3-Pecinan and a small part of Zone 4-Pekojan. Although there is a core zone or buffering zone, all the zones within Jakarta Old Town are a designated area to be conserved and preserved regardless.

As Purwantiasning, et.al (2015)[13] mentioned in her research before, the experience of revitalization in Jakarta is related to conservation of important buildings. Those buildings within Jakarta Old Town have been designated as listed old buildings within Jakarta Old Town Area, and some of them are in a relatively poor condition, physically these buildings need to be revitalized. The local government of Jakarta has been encouraged to enhance the quality of the Jakarta Old Town Area by making it a comfortable place for tourism. One solution has been to created a pedestrian area within the area. The most familiar place to be visited is Fatahillah Square, the area with plaza and pedestrian within surrounding area. Furthermore, there are now pedestrian routes from this plaza to other interesting places within Jakarta Old Town. Visitors can now reach all the attractive places within Jakarta Old Town on foot from one place to others. Although, the possibility to travel on foot could become a lack opportunity for elderly and children, because the area of Jakarta Old Town is relative large from Zone 1- Sunda Kelapa to Zone 2-Fatahillah and other zones. This condition has encourage us to do this research and to propose an alternative solution for better quality within Jakarta Old Town.

Since that one of the issue within this area is lack of infratsructure and facilties, thus will make visitors uncomfortable, we have done this research and proposed a concept of Transit Oriented Development to be implemented within Jakarta Old Town Area. And to support this proposed concept, we have proposed an alternative public transportation within the area which known as tram to support the activities of tourism within the area without interfere and destroy the character of the area as a historical site. This tram is not just a usual public vehicle but it will implement the photovoltaic technology to support the sustainable envrionment by using an alternative solar energy as a main energy to generate the tram.

Figure 3: Jakarta Old Town

Source: Guidelines of Jakarta Old Town (2007) 


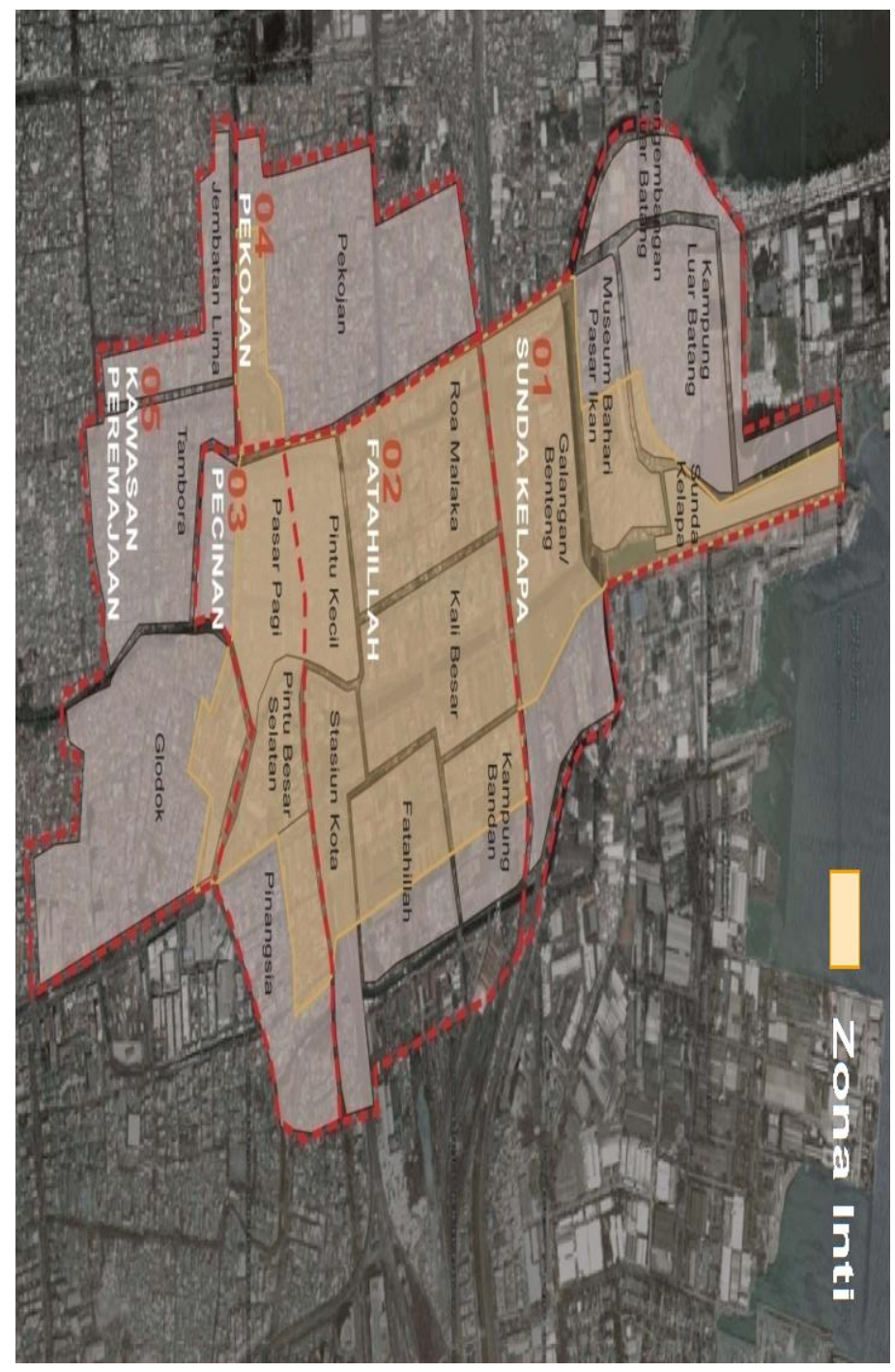

\subsection{The Existing Public Transportation System Surrounding Area}

To propose new public transportation system within historical site particularly Jakarta Old Town Area, we have identified the existing public transportation system within surrounding area of Jakarta Old Town. This existing public transportation system will show either the network will support the proposed concept of Transit Oriented Development or not. We have analyzed also whether this existing public transportation system have supported the activities within Jakarta Old Town or not. By seeing the existing public transportation system within the Jakarta Old Town Area (see Figure 4), we have proposed some point to be a tram stop within the historical area of Jakarta Old Town. Also, we have analyzed the radius of walkable area from one spot to other spots within the area.

Figure 4: Existing Public Transportation 


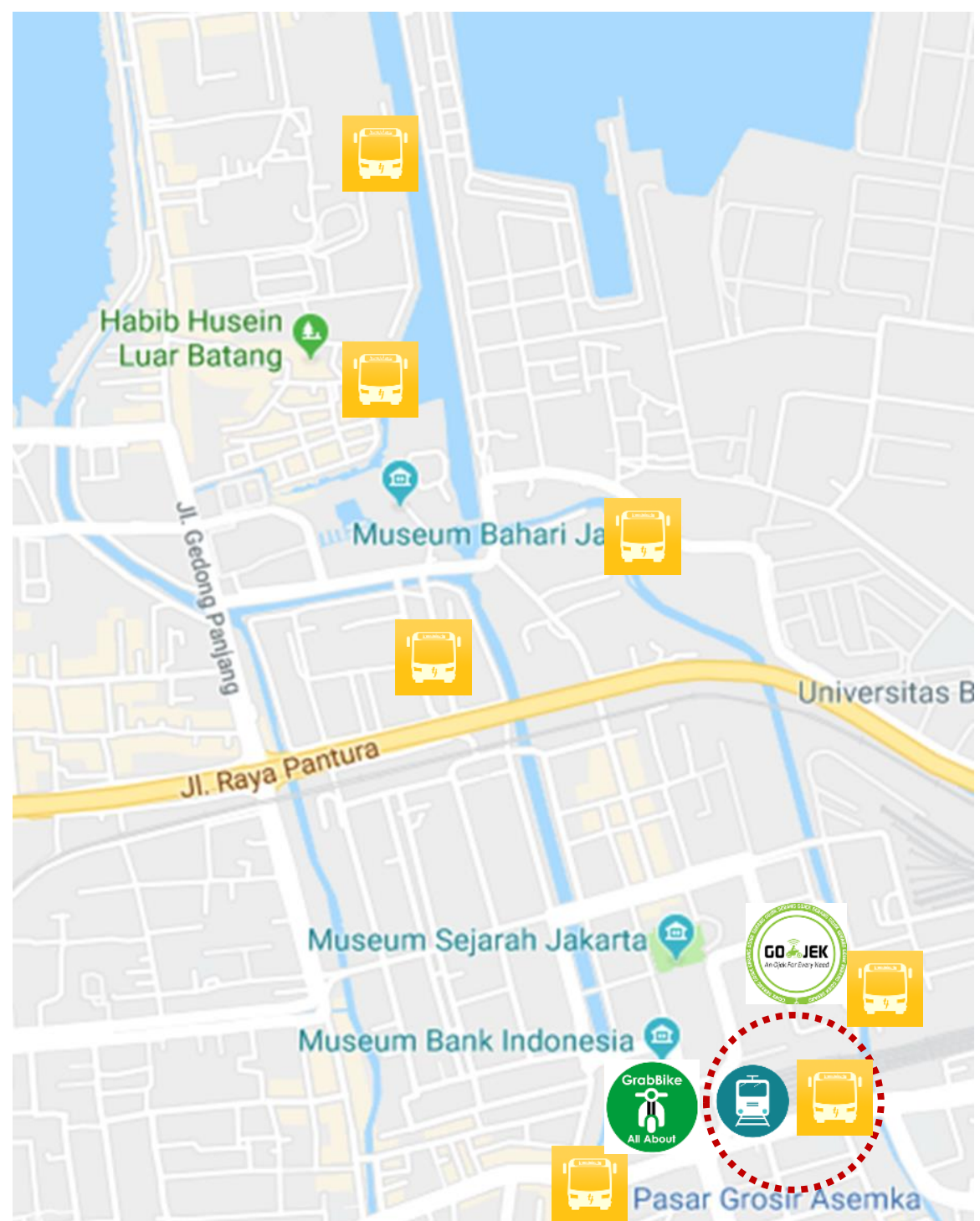

station

Figure Jakarta City as well as the Trans Jakarta Bus Rapid Transit System. The BRT stop is available nearby the train station. Some public transportation that also available nearby the train station are small public vehicles namely "angkot", "bajaj", "bemo" as well as public online service motorcycle called "Gojek" or "Grab".

Figure 4 also shows the network of Trans Jakarta Bus Rapid Transit which has been provided to serve the area of Jakarta Old Town, but the bus stops are relatively far from one

4 shows that there is only one accessible train nearby the historical site of Jakarta Old Town. This train station

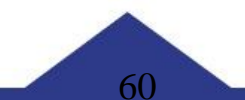


historical spot to others. This condition has encouraged us to propose a new concept of public transportation system which cover the area of Jakarta Old Town without interfere and destroy the character of the historical site.

\subsection{The Point of Interest within Jakarta Old Town}

As mention before, there are many historical buildings within Jakarta Old Town Area which could be explored by visitors. Some of historical buildings have been revitalized to be a new function by implementing an adaptive reused concept. Those historical buildings could be seen in the Figure 5 as follow:

Figure 5: Some historical buildings and point of interest within Jakarta Old Town Area Source: Guidelines of Jakarta Old Town (2007)

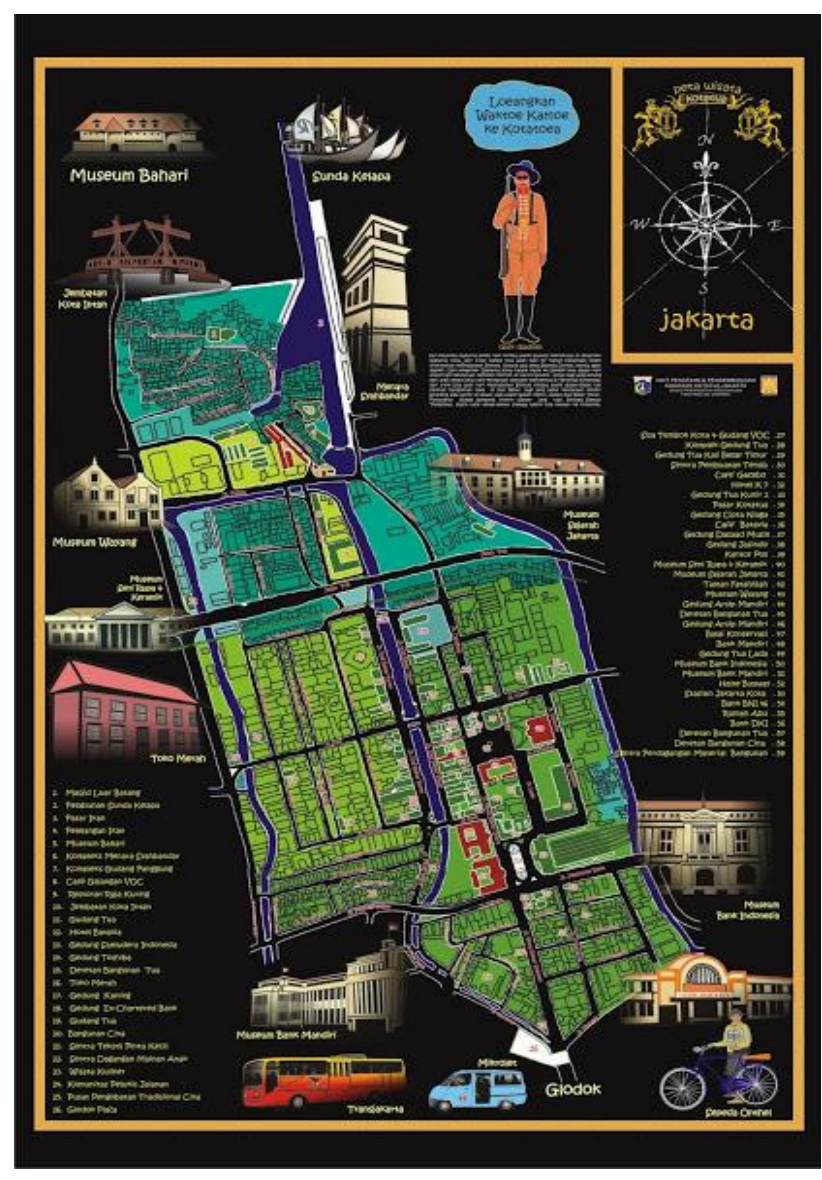

Figure 5

many points of

shows there are interest within Jakarta Old Town Area that could be visited and explored by visitors particularly tourists either from domestic or international. Those historical buildings and sites are located particularly within Zone 1- Sunda Kelapa, Zone 2- Fatahillah and Zone 3- Pecinan or China Town. All the location of historical buildings usually can be reached by walking, although it is relatively large area, but visitors have used the pedestrian way to get one building to others on foot.

\subsection{The Suitable Point for Tram Station}

From the analyzes we have been made, we have proposed some suitable points for tram stop or tram station within historical site of Jakarta Old Town as seen in Figure 6. We have conducted some points using the criteria that we have mentioned in the previous chapter. 
International Conference on Advanced Research in

Figure 6: A proposed suitable point for tram station

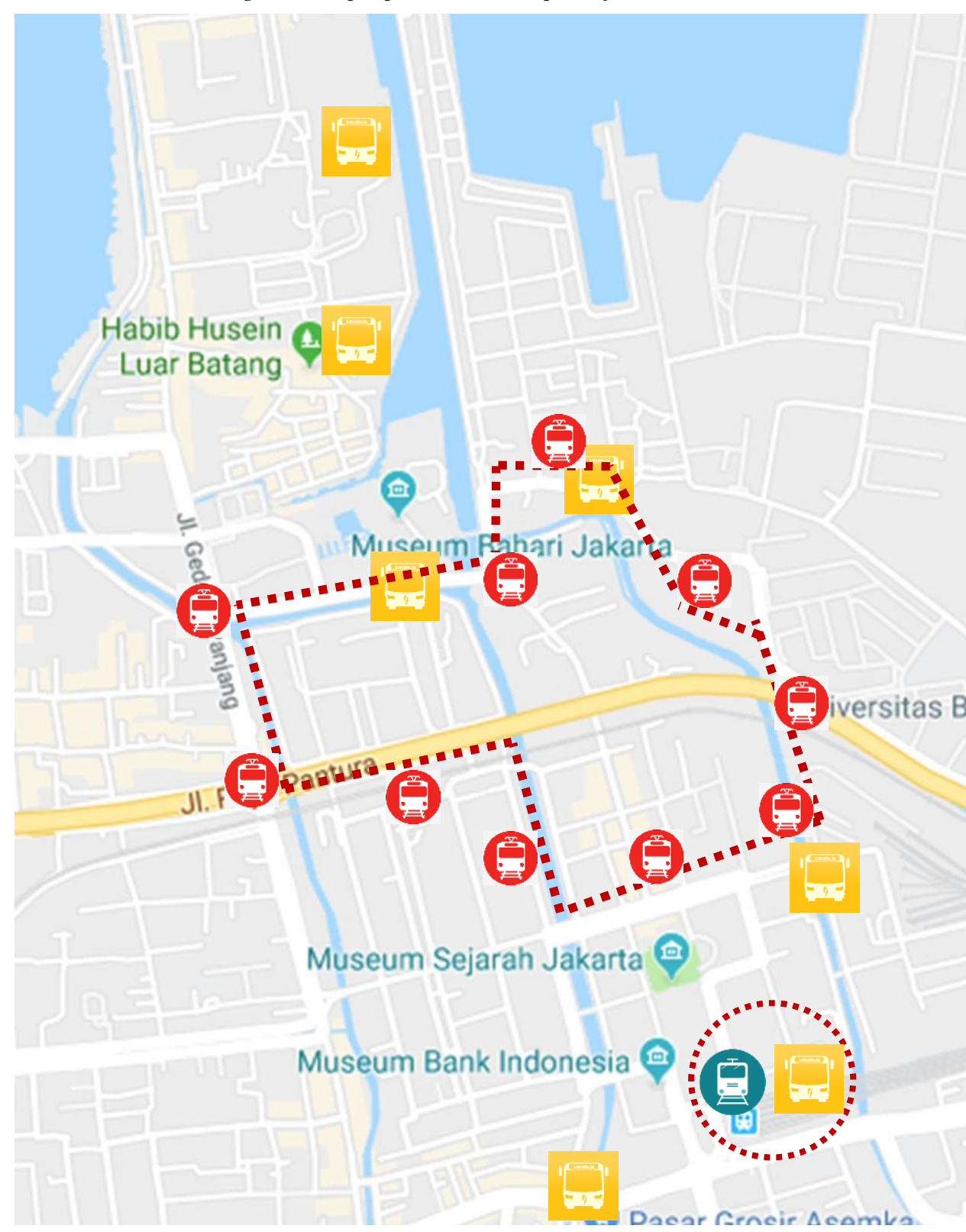

Bus Rapid Transit/ Trans Jakarta

Commuter Line

Tram

To cover the need of local community as well as the visitors within historical site of Jakarta Old Town Area, we have chosen the closest tram station at Fatahillah Square to serve all the visitors from Jakarta Kota Train Station. The proposed service of tram line is looping within historical site of Jakarta Old Town Area, from Fatahillah Square-Canal Batavia-Sunda Kelapa (Maritime Museum and Syahbandar Tower) and back to Fatahillah Square. This proposed alternative solution for public transportation within historical site of 
Jakarta Old Town Area has been conducted to implement and support the concept of Transit Oriented Development within historical site.

\subsection{Proposed Design for Tram System within Jakarta Old Town}

Referring to some references in previous chapter, the technology of photovolltaic for tram is basically the same with car. The difference is about the amount of the energy that will be consumed and needed to generate the tram. As mentioned by Vajihi (2017)[11], there is a first light rail using photovoltaic technology in India. We have adopted this idea to propose and develop the implementation of photovoltaic technology by using solar energy with panels which will be installed on the roof of the tram. We have proposed one unit tram in each trip to avoid the crowding of the historical area particularly during the weekend. We have proposed six package of one unit tram within historical area. We have assumed the trip is about an hour without stoping, and there are 9 stops which need about 10 minutes trip from one stop to another, thus it will need about 90 minutes per trip with 9 stops.

The schematic proposed design for tram system within Jakarta Old Town could be seen in the Figure 7 as follow:

Figure 7: A schematic proposed design for tram system

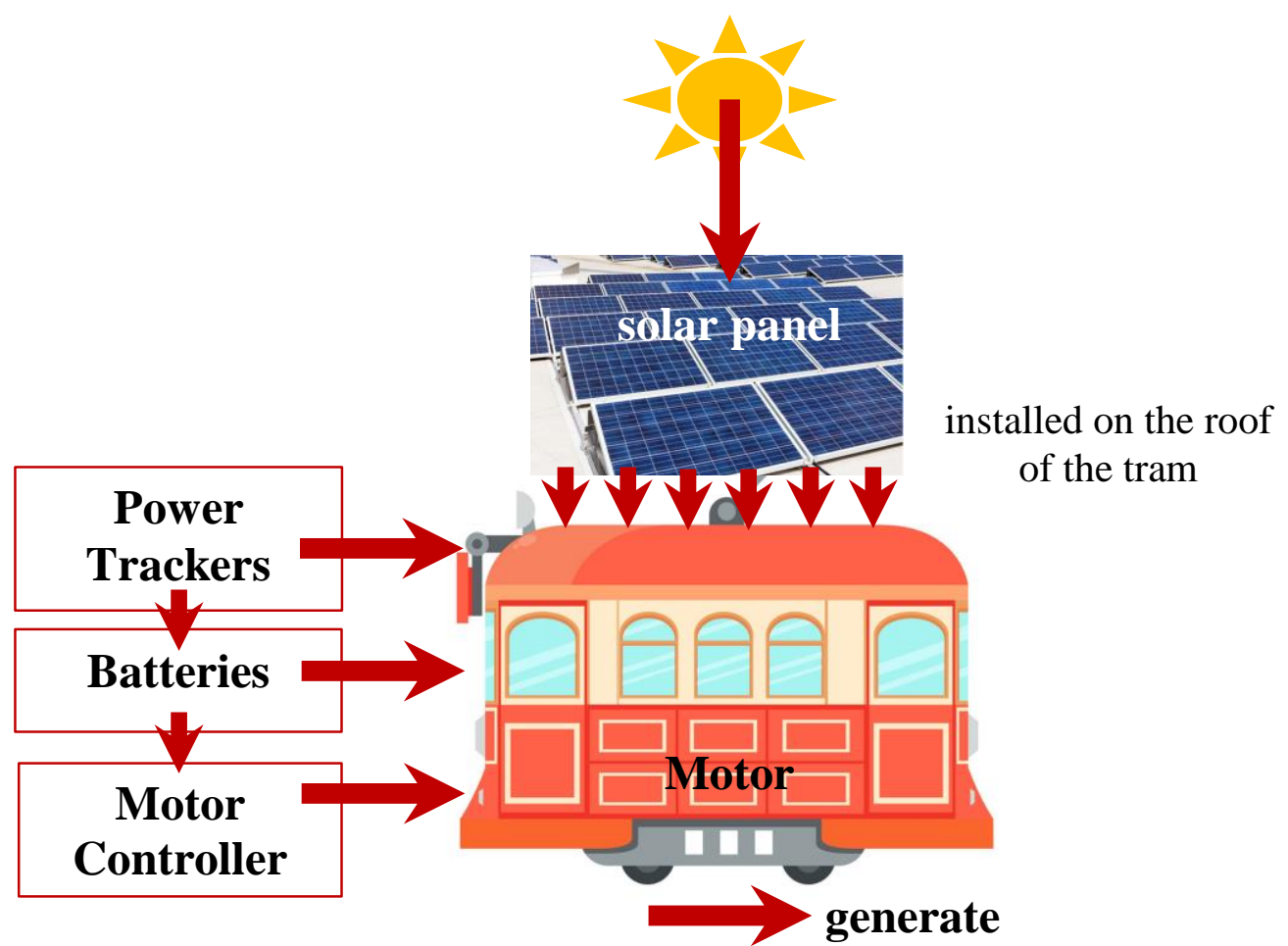

We have analyzed and calculated some

points for the need either the solar panel as well as the need of the unit of the tram to accommodate the passengers in historical site of Jakarta Old Town. There are some criteria that we have to calculate according that, as seen as follow:

1. The specification of the solar panel:

a. Manufacture: C-Sun Solar Panel

b. Dimension: $156 \mathrm{~mm}(\mathrm{~L}) \mathrm{x} 156 \mathrm{~mm}(\mathrm{~W}) \mathrm{x} \quad 0,5 \mathrm{~mm}(\mathrm{~T})$

c. Rate Power: 5,00 watt

d. Quantity Required: 20 panels/ unit tram 
2. The specification of the tram:

a. Power usage of the tram: 100 watt per vehicle

b. Distance in looping trip: $5 \mathrm{~km}$

c. Distance per stops: 1.000 meter

d. Time taken per trip: 60 minutes

e. General power usage per tram per trip one way: 100 watt/ unit tram

f. Frequency from Fatahillah Square to Sunda Kelapa: 10 minutes

g. Frequency from Sunda Kelapa to Fatahillah Square: 10 minutes

h. Number of passengers per unit tram: 40 passengers

According to the above specification and the need, we have concluded that this historical area of Jakarta Old Town Area will need approximately about 6 unit tram per day.

\section{Conclusion}

To explore and understand the application of photovoltaic technology particularly in public transportation facilities, we have conducted some theories and studies about it. Starting from the understanding of the application of PV on private vehicle or car, we have underlined that basically the schematic system of the using solar panel cell for car is relatiively similar to the bigger vehicle in this case is public transportation. We have conducted tram as an alternative public transportation within historical site which we have believed that the implementation of this vehicle system will not alter and destroy the character of the Jakarta Old Town Area.

Giving a calculation of specification and criteria of both need either the tram unit as well as the solar panels, we have concluded that the historical area of Jakarta Old Town could provide some unit of tram within the area to serve the visitors. This idea has been proposed to enhance the quality of the environment as well as the quality of life the local community and visitors. We have proposed the idea of the implementation of photovoltaic technology in public transportation system within historical site of Jakarta Old Town, to support the concept of Transit Oriented Development which will be applied in this site.

\section{Acknowledgement}

This research is a first year research which is a part of a multi-years research which has been started from 2019 to 2020 . This research is a part of a research scheme of Penelitian Dasar Unggulan Perguruan Tinggi. This research has been funded by Kopertis Wilayah III Jakarta, Kementrian Riset, Teknologi dan Pendidikan Tinggi, Direktorat Jenderal Penguatan Riset dan Pengembangan, Indonesia. Number 07/E/KPT/2019, dated 19th February 2019. 
International Conference on Advanced Research in

Applied SCIENCE and ENGINEERING

12 - 14 JULY, 2019

Amsterdam, NETHERLANDS

\section{References}

[1] Güneşer, MT; Erdil, E; Cernat, M and Öztürk, T. (2015). Improving the Energy Management of a Solar Electric Vehicle. Advances in Electrical and Computer Engineering. Volume 15 Number 4, pp. 53-62.

[2] Bahri, S; Purwantiasning, AW. (2018). Modern Thought of Photovoltaic Technology in the Implementation of Transit Oriented Development's Concept and Revitalization of Jakarta Old Town. Proceeding of International Conference on Civil and Environmental Engineering 2018. UTAR, Kuala Lumpur, 03-05 October 2018.

[3] Purwantiasning, AW; Bahri, S. (2017). An Application of Smart Building Concept for Historical Building Using Automatic Control System, Case Study: Fatahillah Museum. International Journal of Built Environment and Scientific Research. Universitas Muhammadiyah Jakarta. Volume 1 No. 2 Ed. December 2017. (2017).

[4] Rizzo, G. (2010). Automotive Application of Solar Energy. Proceeding of $6^{\text {th }}$ IFAC 
Symposium Advance in Automotic Control, Munich, Jerman. $12^{\text {th }}-14^{\text {th }}$ July 2010.

[5] The Midwest Research Institute. Basic Photovoltaci Principles and Methods. (1982). Solar Energy Research Institute. Colorado. United States of America.

[6] Su, Q; Lai, J; Zhang, G; Feng, S; Shi, W. (2010). Flexible Thin Film Solar Cells Using in the Car. World Electric Vehicle Journal, Volume 4 pp. 793-797. Shenzhen, Chna.

[7] Izco, FB. (2010). Fabrication of Solar Panels on the Surface of Solar Car. Thesis Research Report. Publica Universitas Navarrensis. Spanyol.

[8] Taft, N. (2016). Why Don't We Have Solar-Powered Cars?. Fuel Freedom Foundation. Has been accessed on 10th April 2019. USA.

[9] Purwantiasning, AW; Kurniawan, KR. (2018). The Role of Historical Attachment in the Designation of Conservation Areas in Indonesia in The Post-Colonial Era. International Journal of Architecture and Urban Studies. Volume 3 Number 2 pp. 80-87 March 2018. Dakam, Istanbul, Turkey.

[10] Purwantiasning, AW. (2013). Designation of Conservation Area as an Effort to Preserve Local Wisdom. Proceeding of International Seminar on Genius Loci \#01. Universitas Islam Negeri Makassar, Indonesia.

[11] Vajihi, M. (2017). Solar-Powered Light Rail Vehicle and Tram System. Sapienza Universita Di Roma. Italy.

[12] Dinas Kebudayaan dan Permuseuman DKI Jakarta. (2007). Guidelines Kota TuaGuidelines of Jakarta Old Town. DKI Jakarta. Indonesia.

[13] Purwantiasning, AW; Schneider, V; Whittingham, N. (2015). Urban Planning Policies and Strategies for Revitalization: An Overview and Comparison of Experiences from Developed and Developing Regions. Chapter of Revitalizacion de Areas Metropolitanas un Debate Abierto. Instituto de Planeamiento Urbano y Regional, Faculdad de Arquitectura y Urbanismo, Universidad Nacional del Nordeste, Resistencia, Argentina. 